\title{
25 Research Soure \\ Risk Factors of Inability to Exist Independently Among Patients With Lung Cancer
}

\section{Marek Tradecki ( $\nabla$ m.t.1810@interia.pl )}

Social Insurance Institution, Litomska 36, 53-641 Wroclaw, Poland, https://orcid.org/0000-0003-01324536

Jolanta Ziółkowska

Social Insurance Institution

\section{Roma Roemer-Ślimak}

Wroclaw Medical University: Uniwersytet Medyczny im Piastow Slaskich we Wroclawiu

\section{Grzegorz Mazur}

Wroclaw Medical University: Uniwersytet Medyczny im Piastow Slaskich we Wroclawiu

\section{Aleksandra Butrym}

Wroclaw Medical University: Uniwersytet Medyczny im Piastow Slaskich we Wroclawiu

\section{Research article}

Keywords: lung cancer, disability, health impact assessment, palliative care, public health, epidemiology

Posted Date: October 30th, 2020

DOl: https://doi.org/10.21203/rs.3.rs-98060/v1

License: (1) This work is licensed under a Creative Commons Attribution 4.0 International License.

Read Full License 


\section{Abstract}

Background: This study examined risk factors of the inability to live independently among people with lung cancer.

Methods: This paper involved 134 men and women who wanted to get a certificate of the inability to an independent existence issued by the Social Insurance Institution (ZUS). The study protocol was approved by the Commission of Bioethics. The analysis of the results was performed using the IBM SPSS Statistics 26 program.

Results: In the analyzed period, $75 \%$ of people obtained a certificate of the inability to an independent existence (group A) and $25 \%$ did not (group B). In group A $56.4 \%$ of people were men, and in group B $42.4 \%$. In group A $11.8 \%$ of people were diagnosed with small cell lung cancer, no such case was found in group B. Metastases were revealed in $83.2 \%$ of applicants from group A while in $57.6 \%$ from group B. Statistically significantly lower body mass index (BMI) and a lower sum of points in the Barthel Index for Activities of Daily Living (BI) were found in group A compared to group $\mathrm{B}$.

Conclusions: In the authors' opinion, information on BMI, histopathological diagnosis and the presence of metastases are useful in assessing the risk of being unable to live independently in people with lung cancer. BI seems to be helpful in assessing the inability to live independently.

\section{Background}

Lung cancer is a malignant tumor leading to many deaths around the world. In fact it is the main cause of cancer-related mortality worldwide [1-3]. In the literature we can find a variety of works that focus on preventing lung cancer [4-7] and on implications for early detection [8-9]. It is a cancer that causes significant suffering among patients, both physical [10-13] and mental [14-17]. Many articles describe what treatment and which factors are responsible for extending life [18-20] and improving quality of life [21-24]. However, the authors of this article noticed that it is hardly to find studies about the factors causing the inability to live independently in the course of lung cancer. People unable to live independently because of this cancer are a group particularly vulnerable to suffering, they require a holistic approach to care. Therefore, this paper focuses on the risk factors of the inability to live independently in a group of patients with lung cancer. The purpose of determining these factors is to respond quicker to the patients' increased needs and as a result of that minimizing their suffering. Going that way we can also offer this group of patients faster financial assistance to overcome obstacles in their daily life. Many of them have increased financial needs due to their physical and mental state [2527]. Patients who have a certificate of the inability to an independent existence, which is issued among others in Social Insurance Institution (ZUS) by evaluating doctors and medical boards, might be entitled to get nursing supplement or supplementary benefit. In Polish law the answer to the question of who is incapable of independent existence can be found in the Act of 17 December 1998 on pension benefits from the Social Insurance Fund. It is a damage to the organism's ability to function to a degree that 
results in permanent or long-term assistance and care on the part of an another person to satisfy basic life needs.

\section{Methods}

Participants and procedures:

In this study 134 final decisions issued by the Social Insurance Institution in Wrocław in 2016 were analyzed. The leading diagnosis was malignant lung tumor. All these people wanted to get a certificate of the inability to an independent existence. Their files were carefully studied. The informations on age, education and sex were collected. The type of cancer was defined, distant metastases were determined. The functional status of every person was determined on the basis of the Barthel Index for Activities of Daily Living [28] where the maximum number of points is 100 and the minimum is 0 . The Body Mass Index (BMI) was calculated based on the available informations about weight and height. The study protocol was approved by the Commission of Bioethics at Wroclaw Medical University (approval KB331/2019).

Statistical analysis:

The results were subjected to statistical analysis which was performed using the IBM SPSS Statistics 26 program. To assess the significance of the differences among groups, Mann-Whitney $U$ and chi-square tests were performed. The following abbreviations are used in the tables (1-5) with the results of the analysis: „N"-numerical amount, „\%"-percentage, „Chi-2"-statistic of chi-square test, „Z"-statistic of MannWhitney U test, "M"-arithmetic average, „Me”-median, „SD”-standard deviation, „p"-statistical significance of the test. Three levels of statistical significance were adopted: $\left.p<0,001(* \star *), p<0,01{ }^{(* *}\right)$ and $p<0,05(*)$. In each of these three cases we can talk about statistical significance.

\section{Results}

Among 134 analyzed final decisions 101 people (75\%) received a certificate of the inability to an independent existence (these people were included in group A) while 33 people (25\%) did not receive it (these people were included in group B). The groups did not differ significantly in terms of sex $(p=0,161)$. However it should be noted that in group A there were slightly more men and in group B women slightly dominated men (Table 1). The groups do not differ significantly in terms of education $(p=0,376)$. However in group A most people have primary and basic vocational education, group $B$ is clearly dominated by people with basic vocational education (Table 1). The groups differ significantly in terms of histopathological diagnosis $(p=0,045)$. All patients in group $B$ have non-small cell lung cancer (NSCLS) and among those in group A NSCLS is predominant but $11.8 \%$ of patients have a diagnosis of small cell lesion (Table 1). The groups differ significantly in terms of the presence of metastases $(p=0,003)$. They are much more common among people from group $A$ than among people from group $B$ (Table 1 ). 
When comparing groups $A$ and $B$ in terms of age it should be noted that these groups do not differ significantly $(p=0,961)$ from each other (Table 2$)$. In contrast there is a significant statistical difference of the BMI in groups $(p=0,011)$, people from group A have a lower BMI compared to group B (Table 2 ).

A significantly $(p<0,001)$ lower overall score on the Barthel Index for Activities of Daily Living $(B I)$ was recorded in group $A$ (Table 2). People from group $A$ obtained statistically significantly lower results than those from group $B$ on the overall (BI) but also in almost all its subindexes considered separately (Table 3). There is only no significant difference between the groups in the ability to control the urine and the bladder sphincter.

In addition group A was analyzed in terms of sex. There was no statistically significant difference between men and women taking into account (Table 4$)$ : age $(p=0,400)$ and BMI $(p=0,645)$. On the other hand in the case of the Bl: sum of points' difference is close to statistical significance $(p=0,122)$. Higher results were recorded among women than among men (Table 4). In all subindexes of BI considered separately, no statistically significant differences were found between women and men from group A (Table 5). It should be noted, however, that there are differences close to statistical significance in the cases of: grooming, moving and dressing (women are more independent in these matters than men).

\section{Discussion}

To our knowledge this is the first study about risk factors of the inability to live independently among people with lung cancer. In the past attention had already been paid to work not only on gathering information about a lung cancer itself but also on being aware of symptoms for better patients' care [7]. It is connected (among others) with the knowledge of factors that make a damage to the organism's ability to function to a degree that results in permanent or long-term assistance and care on the part of an another person to satisfy basic life needs. Our research shows that people with inability to live independently in the course of this malignant tumor have a lower BMI compared to other people suffering from lung cancer. The available studies show that significant weight loss may impair wound healing and reduce: an ability of immune system, tolerance of treatment and a quality of life [6] which naturally causes a great impairment of the functional state of the human body. We also know that metastases in the course of lung cancer are an important factor influencing the survival time [20]. In our study people with the inability to live independently had significantly more often diagnosed distant metastases in the course of lung cancer than people who were not granted such a certificate. Additionally our observations confirm that small cell lung cancer (SCLC) is a far more aggressive and lethal than NSCLS [29] and that's why SCLS causes greater functional devastation of patients' organism. All persons diagnosed with this form of lung cancer were considered incapable of independent existence. Compared to other malignant tumours lung cancer causes greater unmet needs but these needs have never been fully described [24,30]. Identifying those needs that affect daily functioning could facilitate interventions to improve the quality of life of patients with lung cancer [10], also in group of people with inability to live independently. Physicians of ZUS who issue certificates of the inability to an independent existence often assess patients using the BI. This scale assesses the basic activities of everyday life. This index was originally 
developed for the evaluation of neurological patients, especially those with stroke. However, as our research shows, this scale is also suitable for assessing the unmet needs of a person with lung cancer applying for a certificate of the inability to an independent existence. Persons with a final certificate of the inability to an independent existence had significantly lower results than those who did not receive such a certificate. This confirms that functional performance is an important factor in influencing every day of life of patients with lung cancer [13]. It should also be remembered that despite the advancement in the detection of lung cancer, the possibility of an accurate histopathological diagnosis and access to a wide range of treatments for this cancer, many patients still develop advanced, incurable forms that ultimately lead to death [31] and along the way, at some stage of the disease, often lead to an inability to exist independently.

Our research has several limitations. First of all we were not able to collect informations about treatment of lung cancer in both groups. We also have to remember that not every person with lung cancer applies to ZUS for a certificate of the inability to an independent existence, our study is based on the people who submitted such a request. We analyzed 134 men and women who wanted to get a certificate of the inability to an independent existence issued by the Social Insurance Institution but only in Wroclaw. During data collection we had problems to collect every single information about every single person (for example we had no informations about metastases among six patients in group A). This happened for three reasons, first of all certificates of the inability to an independent existence seldom are issued in absentia, second of all patients rarely don't want to give some informations. Finally, during physicians' examination it may turn out that inability to an independent existence is undisputed and there is no reason to gain additional informations.

\section{Conclusions}

For assessing the risk of being unable to live independently in group of people with lung cancer, in authors' opinion, the useful informations are: BMI, histopathological diagnosis and metastases. No statistically significant differences were observed with such factors as age, education and sex. The BI seems to be helpful in assessing the inability to live independently. However, no statistically significant differences were observed in the BI between women and men who got certificates of the inability to an independent existence. Further research with larger samples and with informations about treatment is needed.

\section{List Of Abbreviations}

ZUS: Social Insurance Institution

BI: Barthel Index for Activities of Daily Living

BMI: body mass index

NSCLS: non-small cell lung cancer 
SCLC: small cell lung cancer

\section{Declarations}

Ethics approval and consent to participate:

The study protocol was approved by the Commission of Bioethics at Wroclaw Medical University (approval KB-331/2019).

Consent for publication:

Not applicable.

Availability of data and materials:

The data that support the findings of this study are available from ZUS but restrictions apply to the availability of these data, which were used under license for the current study, and so are not publicly available. Data are however available from the authors upon reasonable request and with permission of ZUS.

Competing interests:

The authors declare that they have no competing interests.

Funding:

No funding is declared.

Authors' contributions:

MT: research concept, research methodology, collecting material, statistical analysis, interpretations of results, references; JZ: research concept, collecting material, interpretations of results; RRS: statistical analysis, references; GM: research methodology, interpretation of results; AB: research methodology, interpretation of results.

\section{References}

1. Lee SH. Chemotherapy for lung cancer in the era of personalized medicine. Tuberc Respir Dis. 2019; 82 (3):179-189. doi: 10.4046/trd.2018.0068

2. Cho YJ, Cho YM, Kim SH, Shin KH, Jung ST, Kim HS. Clinical analysis of patients with skeletal metastasis of lung cancer. BMC Cancer. 2019; 19:303. doi: 10.1186/s12885-019-5534-3

3. Shahedah KK, How SH, Jamalludin AR, Mohd Faiz MT, Kuan YC, Ong CK. Depressive symptoms in newly diagnosed lung carcinoma: prevalence and associated risk factors. Tuberc Respir Dis. 2019; 82 (3):217-26. doi: $10.4046 /$ trd.2018.0048 
4. Rafiemanesh H, Mehtarpour M, Khani F, Hesami SM, Shamlou R, Towhidi F et al. Epidemiology, incidence and mortality of lung cancer and their relationship with the development index in the world. J Thorac Dis. 2016; 8 (6):1094-102. doi: 10.21037/jtd.2016.03.91

5. Luo Q, Steinberg J, O'Connel DL, Yu XQ, Caruana M, Wade S et al. Lung cancer mortality in Australia in the twenty-first century: how many lives can be saved with effective tobacco control? Lung Cancer. 2019; 130:208-15. doi: 10.1016/j.lungcan.2019.02.028

6. Ge T, Lin T, Yang J, Wang M. Nutritional status and related factors of patients with advanced lung cancer in northern China: a retrospective study. Cancer Management and Research. 2019; 11:222531

7. Arrieta O, Lopez-Meija M, Macedo-Perez EO, Corona-Cruz JF. Proposals for the prevention of lung Cancer in the Health system of Mexico. Salud Publica de Mexico. 2016; 58 (2):274-78

8. Welch LS, Dement JM, Cranford K, Shorter J, Quinn PS, Madtes DK, et al. Early detection of lung cancer in a population at high risk due to occupation and smoking. Occup Environ Med 2019;76:13742.

9. Dement JM, Ringen K, Hines S, Cranford K, Quinn PS. Lung cancer mortality among construction workers: implications for early detection. Occup Environ Med 2020;77:207-13.

10. Steffen LE, Vowles KE, Smith BW, Gan GN, Edelman MJ. Daily diary study of hope, stigma and functioning in lung cancer patients. Health Psychol. 2018; 37 (3):218-27. doi: 10.1037/hea0000570

11. Leppert W, Zajaczkowska R, Wordliczek J, Dobrogowski J, Woron J, Krzakowski M. Pathophysiology and clinical characteristics of pain in most common locations in Cancer patients. Journal of Physiology and Pharmacology. 2016); 67 (6):787-99

12. Zahir ST, Mirtalebi M. Survival of patients with lung cancer, Yazd, Iran. Asian Pacific J Cancer Prev. 2012; 13 (9): 4387-91. doi: 10.7314/APJCP.2012.13.9.4387

13. Lehto RH. Symptom burden in lung cancer: management updates. Lung Cancer Manag. 2016; 5 (2):61-78. doi: 10.2217/Imt-2016-0001

14. Huang X, Yan A, Liu Q, Liu Q, Wu L. Effects of magnanimous therapy on coping, adjustment and living function in advanced lung cancer. Curr Oncol. 2019; 26 (1):e48-e56. doi: 10.3747/co.26.4126

15. Lehto RH. Psychosocial challenges for patients with advanced lung cancer: interventions to improve well-being. Lung Cancer Targets and Therapy. 2017; 8:79-90

16. Xue $F$, Huang $F$. The effect of psychological intervention on nutrient status of perioperative patients with lung cancer. Iran J Public Health. 2018; 47 (4):531-7

17. Oancea C, Suciu C, Timar B, Papava I, Raica M, Burlacu O. The reciprocal relationship between coping mechanisms and lung cancer diagnosis: findings of a prospective study. Cancer Management and Research. 2018; 10:33-40

18. Hellmann MD, Li BT, Chaft JE, Kris MG. Chemotherapy remains an essential element of personalized care for persons with lung cancers. Annals of Oncology. 2016; 27:1829-35. doi: 10.1093/annonc/mdw271 
19. Abedi S, Janbabaei G, Afshari M, Moosazadeh M, Alashti MR, Hedayatizadeh-Omran A et al. Estimating the survival of patients with lung cancer: what is the best statistical model? J Prev Med Public Health. 2019; 52:140-44. doi: 10.3961/jpmph.17.090

20. Abazari M, Gholamnejad M, Roshanaei G, Abazari R, Roosta Y, Mahjub M. Estimation of survival rates in patients with lung cancer in West Azerbaijan, the Northwest of Iran. Asian Pacific J of Cancer Prev. 2015; 16:3923-26. doi: 10.7314/APJCP.2015.16.9.3923

21. Udupa K, Rajendranath R, Sagar TG. Comparison study of quality of life in advanced lung cancer patients on tyrosine kinase inhibitor and platinum doublet chemotherapy. Indian J Cancer. 2017; 54:161-3. doi: 10.4103/0019-509X.219558

22. Gu W, Xu YM, Zhu JH, Zhong BL. Depression and its impact on health-related quality of life among Chinese inpatients with lung cancer. Oncotarget. 2017; 8 (62):104806-12

23. Yun YH, Kim YA, Sim JA, Shin AS, Chang YJ, Lee J et al. Prognostic value of quality of life score in disease-free survivors of surgically treated lung cancer. BMC Cancer. 2016; 16: 505. doi:

10.1186/s12885-016-2504-X

24. Chabowski M, Polanski J, Jankowska-Polanska B, Lomper K, Janczak D, Rosinczuk J. The acceptance of illness, the intensity of pain and the quality of life in patients with lung cancer. $J$ Thorac Dis. 2017; 9 (9):2952-58

25. Wilmowska-Pietruszyńska A. Social security for the disabled and the dependient in Poland. Orzecznictwo Lekarskie. 2007; 4 (1):13-25

26. Wilmowska-Pietruszyńska A. Health, financial and social situation of the disabled and the dependent in Poland. Orzecznictwo Lekarskie. 2009; 6 (1):1-12

27. Wilmowska-Pietruszyńska A. The risk of incapacity for independent living-necessity of social protection. Polityka Zdrowotna. 2012; 10:41-55

28. Mahoney FI, Barthel DQ: Functional evaluation: the Barthel Index. Md State Med J. 1965; 14: 61-65

29. Lundin A, Driscoll B. Lung cancer stem cells: progress and prospects. Cancer Lett. 2013; 338 (1): 89 93. doi: 10.1016/j.canlet.2012.08.014

30. Giuliani ME, Milne RA, Puts M, Sampson LR, Kwan JYY, Le LW et al. The prevalence and nature of supportive care needs in lung cancer patients. Current Oncology. 2016; 23 (4):258-65. doi: $10.3747 /$ co.23.3012

31. Lim RBL. End-of-life care in patients with advanced lung cancer. The Adv Respir Dis. 2016; 10 (5):455-67. doi: 10.1177/1753465816660925

\section{Tables}

Table 1: Informations on sex, education, histopathology and metastases in group A and group B: 


\begin{tabular}{|c|c|c|c|c|c|}
\hline & \multicolumn{5}{|c|}{ Group } \\
\hline & \multicolumn{2}{|c|}{$A(N=101)$} & \multicolumn{2}{|c|}{$B(N=33)$} & \\
\hline SEX & $\mathrm{N}$ & $\%$ & $\mathrm{~N}$ & $\%$ & \multirow{3}{*}{$\begin{array}{l}\text { Chi- } 2=1.960 \\
p=0,161\end{array}$} \\
\hline women & 44 & 43,6 & 19 & 57,6 & \\
\hline \multirow[t]{2}{*}{ men } & 57 & 56,4 & 14 & 42,4 & \\
\hline & \multicolumn{2}{|c|}{$A(N=88)^{1}$} & \multicolumn{2}{|c|}{$B(N=33)$} & \multirow{6}{*}{$\begin{array}{l}\text { Chi- } 2=3,107 \\
p=0,376\end{array}$} \\
\hline EDUCATION & $\mathrm{N}$ & $\%$ & $\mathrm{~N}$ & $\%$ & \\
\hline primary & 33 & 37,5 & 7 & 21,2 & \\
\hline basic vocational & 33 & 37,5 & 16 & 48,5 & \\
\hline secondary & 17 & 19,3 & 7 & 21,2 & \\
\hline \multirow[t]{2}{*}{ higher } & 5 & 5,7 & 3 & 9,1 & \\
\hline & \multicolumn{2}{|c|}{$A(N=93)^{2}$} & \multicolumn{2}{|c|}{$B(N=31)^{3}$} & \\
\hline HISTOPATHOLOGY & $\mathrm{N}$ & $\%$ & $\mathrm{~N}$ & $\%$ & \\
\hline small cell lung cancer & 11 & 11,8 & 0 & 0 & Chi- $2=4,024$ \\
\hline \multirow[t]{2}{*}{ non-small cell lung cancer } & 82 & 88,2 & 31 & 100 & $p=0,045^{\star}$ \\
\hline & \multicolumn{2}{|c|}{$A(N=95)^{4}$} & \multicolumn{2}{|c|}{$B(N=33)$} & \\
\hline METASTASES & $N$ & $\%$ & $\mathrm{~N}$ & $\%$ & \\
\hline no & 16 & 16,8 & 14 & 42,4 & Chi-2=8,933 \\
\hline yes & 79 & 83,2 & 19 & 57,6 & $p=0,003^{\star *}$ \\
\hline
\end{tabular}

${ }^{1}$ no informations about 13 persons

${ }^{2}$ no informations about 8 persons

${ }^{3}$ no informations about 2 persons

${ }^{4}$ no informations about 6 persons

Table 2: Informations on age, $\mathrm{BMI}$ and $\mathrm{BI}$ in group $\mathrm{A}$ and group $\mathrm{B}$ : 


\begin{tabular}{|c|c|c|c|c|c|c|c|c|}
\hline & \multicolumn{6}{|c|}{ Group } & & \\
\hline & A & & & B & & & & \\
\hline & M & $\mathrm{Me}$ & SD & $M$ & $\mathrm{Me}$ & SD & Z & $\mathrm{p}$ \\
\hline Age & 65,34 & 66,00 & 5,92 & 65,73 & 65,00 & 4,28 & $-0,049$ & 0,961 \\
\hline $\mathrm{BMI}^{1}$ & 24,23 & 23,99 & 4,80 & 26,76 & 27,69 & 4,68 & $-2,527$ & $0,011^{*}$ \\
\hline$\left.B\right|^{1}$ & 56,24 & 60,00 & 15,70 & 89,70 & 90,00 & 7,70 & $-8,302$ & $<0,001^{\star \star \star}$ \\
\hline
\end{tabular}

${ }^{1}$ No informations about 16 persons in group $\mathrm{A}$

Table 3: Barthel Index for Activities of Daily Living (BI) in group A and group B: 


\begin{tabular}{|c|c|c|c|c|c|}
\hline \multicolumn{6}{|c|}{ Group } \\
\hline & $A(1$ & $=85)^{1}$ & $B(1$ & =33) & \\
\hline FEEDING & $\mathrm{N}$ & $\%$ & $\mathrm{~N}$ & $\%$ & \multirow{4}{*}{$Z=-6,425, p<0,001^{\star \star \star}$} \\
\hline unable & 4 & $4,7 \%$ & 0 & $0,0 \%$ & \\
\hline needs help & 58 & $68,2 \%$ & 2 & $6,1 \%$ & \\
\hline independent & 23 & $27,1 \%$ & 31 & $93,9 \%$ & \\
\hline TRANSFERS (BED TO CHAIR AND BACK) & $\mathrm{N}$ & $\%$ & $\mathrm{~N}$ & $\%$ & \multirow{5}{*}{$Z=-7,841, p<0,001^{* \star *}$} \\
\hline unable & 4 & $4,7 \%$ & 0 & $0,0 \%$ & \\
\hline major help & 18 & $21,1 \%$ & 1 & $3,0 \%$ & \\
\hline minor help & 57 & $67,1 \%$ & 1 & $3,0 \%$ & \\
\hline independent & 6 & $7,1 \%$ & 31 & $94,0 \%$ & \\
\hline GROOMING & $\mathrm{N}$ & $\%$ & $\mathrm{~N}$ & $\%$ & \multirow{3}{*}{$Z=-2,702, p=0,007 \star \star$} \\
\hline needs help (personal care) & 21 & $24,7 \%$ & 1 & $3,0 \%$ & \\
\hline independent & 64 & $75,3 \%$ & 32 & $97,0 \%$ & \\
\hline TOLIET USE & $\mathrm{N}$ & $\%$ & N & $\%$ & \multirow{4}{*}{$Z=-4,628, p<0,001^{\star \star \star}$} \\
\hline dependent & 6 & $7,1 \%$ & 0 & $0,0 \%$ & \\
\hline needs some help & 42 & $49,4 \%$ & 3 & $9,1 \%$ & \\
\hline independent & 37 & $43,5 \%$ & 30 & $90,9 \%$ & \\
\hline BATHING & $\mathrm{N}$ & $\%$ & $\mathrm{~N}$ & $\%$ & \multirow{3}{*}{$Z=-5,106, p<0,001^{* \star *}$} \\
\hline dependent & 83 & $97,6 \%$ & 21 & $63,6 \%$ & \\
\hline independent & 2 & $2,4 \%$ & 12 & $36,4 \%$ & \\
\hline MOBILITY (FLAT TERRAIN) & $\mathrm{N}$ & $\%$ & N & $\%$ & \multirow{5}{*}{$Z=-6,386, p<0,001^{* * *}$} \\
\hline immobile or $<50 \mathrm{~m}$ & 33 & $38,8 \%$ & 1 & $3,0 \%$ & \\
\hline wheelchair independent ${ }^{2}$ & 7 & $8,2 \%$ & 0 & $0,0 \%$ & \\
\hline walks with help of 1 person ${ }^{2}$ & 44 & $51,8 \%$ & 15 & $45,5 \%$ & \\
\hline independent, may use an aid ${ }^{2}$ & 1 & $1,2 \%$ & 17 & $51,5 \%$ & \\
\hline STAIRS & $\mathrm{N}$ & $\%$ & N & $\%$ & \multirow[b]{3}{*}{$Z=-8,140, p<0,001^{\star \star \star}$} \\
\hline unable & 32 & $37,6 \%$ & 0 & $0,0 \%$ & \\
\hline needs help & 52 & $61,2 \%$ & 5 & $15,2 \%$ & \\
\hline
\end{tabular}




\begin{tabular}{|c|c|c|c|c|c|}
\hline independent & 1 & $1,2 \%$ & 28 & $84,8 \%$ & \\
\hline DRESSING & $\mathrm{N}$ & $\%$ & $\mathrm{~N}$ & $\%$ & \multirow{4}{*}{$Z=-7,094, p<0,001^{\star \star \star}$} \\
\hline dependent & 7 & $8,2 \%$ & 0 & $0,0 \%$ & \\
\hline needs help & 59 & $69,4 \%$ & 1 & $3,0 \%$ & \\
\hline independent & 19 & $22,4 \%$ & 32 & $97,0 \%$ & \\
\hline BOWELS & $\mathrm{N}$ & $\%$ & $\mathrm{~N}$ & $\%$ & \multirow{4}{*}{$Z=-2,626, p=0,009 * \star$} \\
\hline incontinent; needs enemas & 5 & $5,9 \%$ & 0 & $0,0 \%$ & \\
\hline occasional accident & 19 & $22,4 \%$ & 2 & $6,1 \%$ & \\
\hline continent & 61 & $71,7 \%$ & 31 & $93,9 \%$ & \\
\hline BLADDER & $\mathrm{N}$ & $\%$ & $\mathrm{~N}$ & $\%$ & \multirow{4}{*}{$Z=-0,911, p=0,362$} \\
\hline incontinent; catherized & 4 & $4,8 \%$ & 1 & $3,0 \%$ & \\
\hline occasional accident & 32 & $37,6 \%$ & 10 & $30,3 \%$ & \\
\hline continent & 49 & $57,6 \%$ & 22 & $66,7 \%$ & \\
\hline
\end{tabular}

${ }^{1}$ No informations about 16 persons in group $\mathrm{A}$

${ }^{2}$ over 50 metres

Table 4: Informations on age, $\mathrm{BMI}$ and $\mathrm{BI}$ in group $\mathrm{A}$ (women and men)

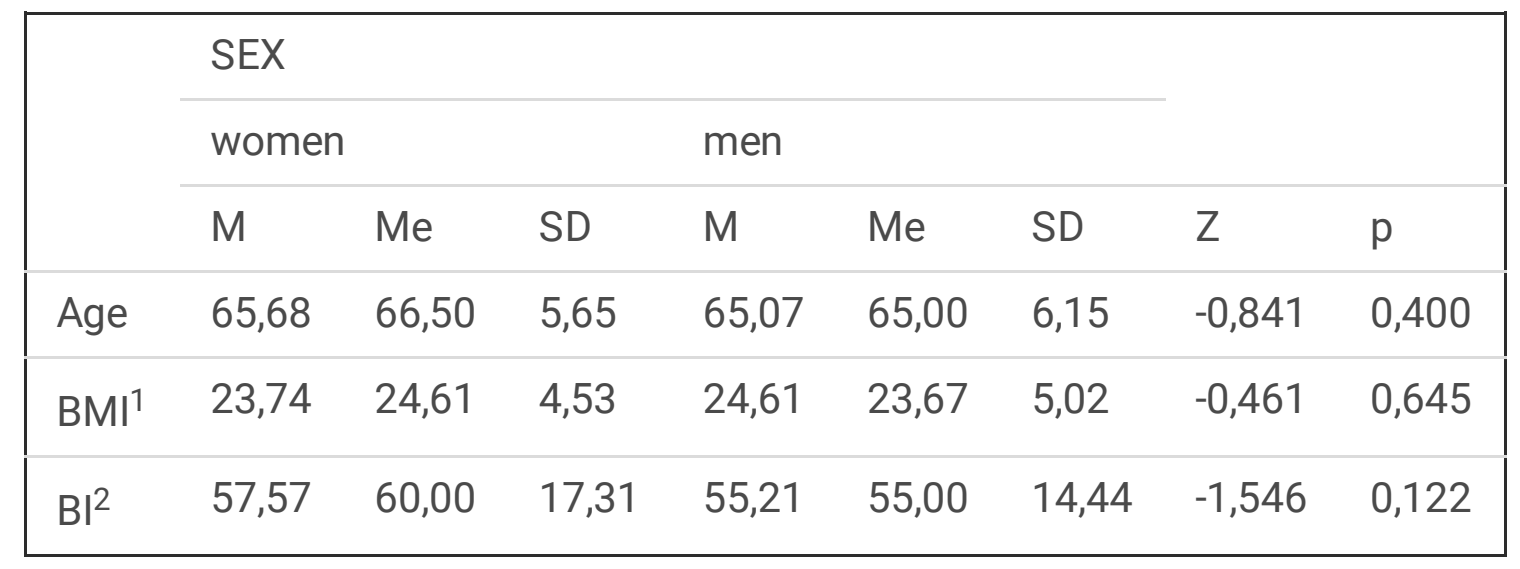

${ }^{1}$ No informations about 11 women and 5 men

${ }^{2}$ No informations about 7 women and 9 men 
Table 5: Barthel Index for Activities of Daily Living (BI) in group A (men "Mn" and women "Wo") 


\begin{tabular}{|c|c|c|c|c|c|}
\hline \multirow[b]{3}{*}{ FEEDING } & \multicolumn{5}{|c|}{ SEX } \\
\hline & \multicolumn{2}{|c|}{ Wo $(N=37)^{1}$} & \multicolumn{2}{|c|}{$\mathrm{Mn}(\mathrm{N}=48)^{2}$} & \\
\hline & $\mathrm{N}$ & $\%$ & $\mathrm{~N}$ & $\%$ & \multirow{4}{*}{$Z=-0,348, p=0,727$} \\
\hline unable & 2 & $5,4 \%$ & 2 & $4,2 \%$ & \\
\hline needs help & 24 & $64,9 \%$ & 34 & $70,8 \%$ & \\
\hline independent & 11 & $29,7 \%$ & 12 & $25,0 \%$ & \\
\hline TRANSFERS (BED TO CHAIR AND BACK) & $\mathrm{N}$ & $\%$ & $\mathrm{~N}$ & $\%$ & \multirow{5}{*}{$Z=-0,069, p=0,945$} \\
\hline unable & 2 & $5,4 \%$ & 2 & $4,2 \%$ & \\
\hline major help & 8 & $21,6 \%$ & 10 & $20,8 \%$ & \\
\hline minor help & 24 & $64,9 \%$ & 33 & $68,8 \%$ & \\
\hline independent & 3 & $8,1 \%$ & 3 & $6,2 \%$ & \\
\hline GROOMING & $\mathrm{N}$ & $\%$ & $\mathrm{~N}$ & $\%$ & \multirow{3}{*}{$Z=-1,584, p=0,113$} \\
\hline needs help (personal care) & 6 & $16,2 \%$ & 15 & $31,2 \%$ & \\
\hline independent & 31 & $83,8 \%$ & 33 & $68,8 \%$ & \\
\hline TOLIET USE & $\mathrm{N}$ & $\%$ & $\mathrm{~N}$ & $\%$ & \multirow{4}{*}{$Z=-0,134, p=0,893$} \\
\hline dependent & 3 & $8,2 \%$ & 3 & $6,2 \%$ & \\
\hline needs some help & 18 & $48,6 \%$ & 24 & $50,0 \%$ & \\
\hline independent & 16 & $43,2 \%$ & 21 & $43,8 \%$ & \\
\hline BATHING & $\mathrm{N}$ & $\%$ & $\mathrm{~N}$ & $\%$ & \multirow{3}{*}{$Z=-1,249, p=0,212$} \\
\hline dependent & 37 & $100,0 \%$ & 46 & $95,8 \%$ & \\
\hline independent & 0 & $0,0 \%$ & 2 & $4,2 \%$ & \\
\hline MOBILITY (FLAT TERRAIN) & $\mathrm{N}$ & $\%$ & $\mathrm{~N}$ & $\%$ & \multirow{5}{*}{$Z=-1,430, p=0,153$} \\
\hline immobile or $<50 \mathrm{~m}$ & 11 & $29,7 \%$ & 22 & $45,8 \%$ & \\
\hline wheelchair independent ${ }^{3}$ & 3 & $8,1 \%$ & 4 & $8,3 \%$ & \\
\hline walks with help of 1 person ${ }^{3}$ & 23 & $62,2 \%$ & 21 & $43,8 \%$ & \\
\hline independent, may use an aid ${ }^{3}$ & 0 & $0,0 \%$ & 1 & $2,1 \%$ & \\
\hline STAIRS & $\mathrm{N}$ & $\%$ & $N$ & $\%$ & \multirow[b]{3}{*}{$Z=-0,288, p=0,774$} \\
\hline unable & 13 & $35,1 \%$ & 19 & $39,6 \%$ & \\
\hline needs help & $\begin{array}{l}24 \\
\text { Page } 1\end{array}$ & $64,9 \%$ & 28 & $58,3 \%$ & \\
\hline
\end{tabular}




\begin{tabular}{|c|c|c|c|c|c|}
\hline independent & 0 & $0,0 \%$ & 1 & $2,1 \%$ & \\
\hline DRESSING & $\mathrm{N}$ & $\%$ & $\mathrm{~N}$ & $\%$ & \multirow{4}{*}{$Z=-1,611, p=0,107$} \\
\hline dependent & 3 & $8,1 \%$ & 4 & $8,3 \%$ & \\
\hline needs help & 22 & $59,5 \%$ & 37 & $77,1 \%$ & \\
\hline independent & 12 & $32,4 \%$ & 7 & $14,6 \%$ & \\
\hline BOWELS & $\mathrm{N}$ & $\%$ & $\mathrm{~N}$ & $\%$ & \multirow{4}{*}{$Z=-0,090, p=0,928$} \\
\hline incontinent; needs enemas & 3 & $8,1 \%$ & 2 & $4,2 \%$ & \\
\hline occasional accident & 7 & $18,9 \%$ & 12 & $25,0 \%$ & \\
\hline continent & 27 & $73,0 \%$ & 34 & $70,8 \%$ & \\
\hline BLADDER & $\mathrm{N}$ & $\%$ & $\mathrm{~N}$ & $\%$ & \multirow{4}{*}{$Z=-0,780, p=0,435$} \\
\hline incontinent; catherized & 3 & $8,1 \%$ & 1 & $2,1 \%$ & \\
\hline occasional accident & 14 & $37,8 \%$ & 18 & $37,5 \%$ & \\
\hline continent & 20 & $54,1 \%$ & 29 & $60,4 \%$ & \\
\hline
\end{tabular}

${ }^{1}$ No informations about 7 persons (Barthel Index)

${ }^{2}$ No informations about 9 persons (Barthel Index)

${ }^{3}$ over 50 metres 